\title{
INTRA-ENTERPRISE CONSPIRACY UNDER THE SHERMAN ACT
}

IN recent years courts have found conspiracy to violate the Sherman Act ${ }^{1}$ within the integrated multi-corporate enterprise. ${ }^{2}$ Unlike the offense of monopolizing, a conspiracy to monopolize or to restrain trade requires "joint action" by at least two parties. ${ }^{3}$ But, even where there is unified ownership, separate corporations are held to be separate persons. ${ }^{4}$ Thus, a parent corporation and its subsidiaries, whether wholly or partially owned, can conspire. For example, should the Ford Motor Company wish to divide Ford, Lincoln, and Mercury into separate subsidiary corporations, agreements to fix prices or set production quotas for each line might be illegal.5 Perhaps even the directors, officers, and agents of a single corporation can conspire. ${ }^{\circ}$ If so, a wide range of corporate activities, now considered immune from Sherman Act

1. Section 1 provides:

"Every contract, combination ...., or conspiracy, in restraint of trade or commerce among the several States, or with foreign nations, is hereby declared to be illegal. . .."

Section 2 provides:

"Every person who shall monopolize, or attempt to monopolize, or combine or conspire with any other person or persons, to monopolize any part of the trade or commerce among the several States, or with foreign nations, shall be guilty of a misdencanor. . .." 26 Stat. 209 (1890), 15 U.S.C. §§ 1, 2 (1946).

2. For discussion of intra-enterprise conspiracy, see Rahl, Conspiracy and the Antitrust Lazes, 44 IlL. L. Rev. 743, 762 (1950) ; Comment, 47 Col. L. Rev. 786, 788 (1947) ; Notes, 43 Il. L. Rev. 551 (1948); 100 U. of PA. L. Rev. 1006, 1010 (1952).

3. For historical explanation of the joint action requirement, see Rahl, silpra note 2 , at 744 , and sources cited therein.

4. Timken Roller Bearing Co. v. United States, 341 U.S. 593 (1951) (affiliates); Kiefer-Stewart Co. v. Seagram \& Sons, 340 U.S. 211 (1951) (same); Schine Chain Theaters v. United States, 334 U.S. 110 (1948) (parent and subsidiaries); United States v. General Motors Corp., 121 F.2d 376 (7th Cir.), cert. denied, 314 U.S. 618 (1941) (same).

5. Price-fixing and market division by independent companies are clearly illegal, United States v. Socony-Vacuum Oil Co., 310 U.S. 150, 223 (1940) (price-fixing); United States v. Trenton Potteries Co., 273 U.S. 392, 399 (1926) (same); United States v. Addyston Pipe \& Steel Co., 85 Fed. 271, 293 (6th Cir. 1898), aff'd, 175 U.S. 211 (1899) (market division); United States v. National Lead Co., 63 F. Supp. 513, 523 (1945), aff'd, 332 U.S. 319 (1947) (same).

6. White Bear Theater Corp. y. State Theater Corp., 129 F.2d 600, 602 (8th Cir. 1942) (officers of single corporation); Patterson v. United States, 222 Fed. 599, 633 (6th Cir.), cert. denied, 238 U.S. 635 (1915) (same). Contra: Nelson Radio \& Supply Co. v. Motorola, Inc., 200 F.2d 911 (5th Cir. 1952), cert. denied, 345 U.S. 925 (1953) ; Marion County Co-op. Ass'n v. Carnation Co., 114 F. Supp. 58 (W.D. Ark. 1953).

For legal argument in favor of intra-corporate conspiracy doctrine, sce Kramer, Does Concerted Action Solely between a Corporation and Its Officers Acting on Its Bchalf in Unreasonable Restraint of Interstate Commerce Violate Section 1 of The Sherman Act?, 11 FED. B.J. 130 (1951). 
prosecution, could arguably fall within its ban. Fearing a threat to American business in the far-reaching implications of the intra-enterprise conspiracy doctrine, some commentators have attacked its growth, tagging the concept "corporate self-abuse"7 and "bath tub conspiracy."8 Others view it hopefully as the instrument for a "second crack" at the concentration of industry."

\section{Conspiracy within the Multi-CoRporate Enterprise}

In the modern business world a single enterprise, acting alone, may exert considerable power over its competitors, customers, and suppliers. A dominant producer such as U.S. Steel can foreclose a part of the steel fabricating market to competing producers by buying up and merging with an independent fabricator. ${ }^{10}$ A large seller like General Motors can force independent dealers to finance wholesale and retail automotive purchases through its financing subsidiary by threatening to cut off their supply of GMI cars. ${ }^{11} \mathrm{~A}$ large buyer like A \& P can force its suppliers to grant lower prices to itself than to its competitors by threatening either to take its business elsewhere or to become its own supplier. ${ }^{12}$

Conspiracy aside, each of the above single-trader abuses may fall within the prohibitions of the antitrust laws. If motivated by an intent to monopolize. U. S. Steel may violate the Sherman Act's Section 2 prohibition of monopolizing or attempting to monopolize when it forecloses a market to competitors by merging with an independent fabricator. ${ }^{13}$ The same merger may also violate Section 1 prohibitions against combinations in restraint of trade. ${ }^{14}$ General Motors' financing arrangement is similar to a tie-in sale prohibited by the Clayton Act. ${ }^{15}$ A \& $\mathrm{P}$ may violate the Robinson-Patman . Ict by inducing its suppliers to grant it discriminatory prices. ${ }^{10}$

Moreover, the doctrine that a single enterprise can conspire within itself may give the antitrust prosecutor an alternative theory of illegality with which

7. Adelman, Integration and Antitrust Policy, 63 HAnv. L. REv. 27, 51 (1949).

8. Searls, The Antitrust Laws from the Vicwpoint of a Prieate Pratitioner in 1950 Institute on Antitrust Laws and Price-Regulations 71, $\$ 6$ (1950).

9. Note, 100 U. of PA. L. REv. 1006, 1023 (1952). "At present, the theoretical possibilities of the ... doctrine far outmeasure its prospects." Id. at 1025.

10. See text at note 53 infra.

11. See text at note 25 infra.

12. See text at note 40 infra.

13. United States v. Columbia Steel Co., 334 U.S. 495, $531-3$ (1943). For conflicting interpretations of leading $\$ 2$ cases compare Rostow, Monopoly Under the Shornon Aet: Power or Purpose?, 43 ILx L. Fev. 745 (1949), with Johnston \& Stevens, Moropoly or Monopolization: A Reply to Professor Rostow, 44 ILL. L. KEv. 269 (1949).

14. United States v. Reading Co., 226 U.S. 324 (1912); Northern Sceurities Co. v. United States, 193 U.S. 197 (1904).

The merger may also violate $\$ 7$ of the Clayton Act. See Note, 63 YaLE LJ. 233 (1953).

15. See note 29 infra.

16. Note, 47 CoL. L. REv. 786, 795 (1947). See also Note, 63 YALE L.J. 260 (1953). 
to combat each of the above practices. Although an intra-enterprise conspiracy may be alleged under Section 2's monopoly provisions, the intra-enterprise conspiracy doctrine has been largely a device for bringing single-trader abuses within Section 1's ban on conspiracy in restraint of trade. The advantages of a Section 1 prosecution may include criminal penalties, ${ }^{17}$ treble damage relief, ${ }^{18}$ avoidance of unfavorable precedent, ${ }^{10}$ and the elimination of certain defenses. ${ }^{20}$ Even where the plaintiff already has a Section 1 allegation based on contract or combination, an allegation of conspiracy may lighten his burden of proof ${ }^{21}$ or extend the statute of limitations. ${ }^{22}$

So, in order to avail themselves of such advantages, antitrust prosecutors, alleging conspiracy, have attempted to establish the necessary "joint action" within the confines of the single enterprise. And, in large measure, courts have viewed these attempts with favor, looking more to the economic abuses before them than to the doctrinal issue presented. Thus, the intra-enterprise conspiracy doctrine has developed as an ad hoc response to the needs of the litigator rather than to foster a clearly-defined economic policy. Judicial failure to impose conceptual limitations on the doctrine has given rise to speculation concerning its application to factual situations yet unlitigated. The following case-by-case study of intra-enterprise conspiracy illustrates the growth of the doctrine and suggests direction for both its extension and limitation.

\section{Abuses of Market Power}

Tie-in sales: the GMAC Case. ${ }^{23}$ In 1941 the Seventh Circuit upheld a criminal conviction of General Motors under Section 1 of the Sherman Act. ${ }^{24}$

17. See text at note 30 infra.

18. See text at note 102 infra.

19. See note 30 infra and accompanying text.

20. See, e.g., United States v. New York Great Atlantic \& Pacific Tea Co., 173 F.2d 79, 89 (7th Cir. 1949) (defense of compliance with Robinson-Patman Act and FTC order).

21. See text at note 51 infra.

22. United States v. Kissel, 218 U.S. 601, 607 (1910) (conspiracy to drive competitors out of business continues until abandoned); United States v. Trans-Missouri Freight Ass'n, 166 U.S. 290, 342 (1897) (continuing conspiracy to peg freight rates).

23. United States v. General Motors Corp., 121 F.2d 376 (7th Cir.), cert. denicd, 314 U.S. 618 (1941), 30 CALIF. L. Rev. 204 (1942); 17 Ind. L.J. 255 (1942).

24. The Government brought simultaneous criminal actions against General Motors, Ford, and Chrysler for similar practices. Ford and Chrysler entered into consent dccrees contingent on the outcome of the General Motors litigation. Since the General Motors litigation dragged on for twelve years, there was the continuing problem of how long Ford's and Chrysier's consent decrees should be extended. Compare Chrysler Corp. v. United States, 316 U.S. 556 (1942) (extension granted to Government), with Ford Motor Co. v. United States, 335 U.S. 303 (1948) (no extension). See full disctussion in Haberman \& Birnbaum, Auto-Finance Consent Decree: an Epiloguc, [1950] Wasu. U.L.Q. 46. In 1952 a consent decree finally terminated the Government's civil action against General Motors. United States v. General Motors Corp., CCH TrADE REG. REp. 
The manufacturing corporation was held to have conspired with its whollyowned sales and financing subsidiaries to compel independent dealers holding GMI franchises to finance the wholesale and retail sales of GMI cars through the General Motors Acceptance Corporation (GMI.AC).25 Special concessions were made to cooperating dealers. Non-conformers had difficulty in obtaining prompt delivery. If necessary, threats of franchise termination proved an effective means of coercion.

General Motors defended on the ground that they were a single-trader..6 Their argument had two parts. First, the joint action requirement of Section 1 forecloses a conspiracy finding when the parties are non-competing units of a single enterprise. Second, since the enterprise was merely exercising its right of refusal to deal, the single-trader was at most legally restraining its own commerce.

The court rejected both aspects of the single-trader defense. ${ }^{27}$ Disregarding GM's unified ownership. the court held each corporate instrumentality-manufacturing, sales, and financing-a separate person for purposes of conspiracy. When defendants enjoy the benefits of multi-corporate form, they face the risk of Section 1 liability. Furthermore, said the the court, GMI was restraining not its own trade, but the commerce of third parties. ${ }^{25}$ Restrictions on financing might hinder purchases of GMI cars. And, since title passed at the manufacturer's point of shipment, dealers' commerce in GMI cars was the trade restrained. Furthermore, requiring exclusive use of GMAC forced other finance companies out of lucrative business in automobile paper.

Defendants probably could not avoid antitrust liability on this issue by reorganizing into a single corporation. In essence GMI's practice was a tie-in sale, forbidden by Section 3 of the Clayton Act. ${ }^{29}$ The defendants were using a legal monopoly (that in GMI cars) to gain advantages in another market (that for financing). The court's conspiracy theory merely provides prosecutors with greater latitude in selecting a theory of illegality. In the GMLAC case, for example, by alleging a Section 1 conspiracy, the prosecution secured criminal sanctions unavailable under the Clayton Act, and also avoided unfavorable precedent that had developed under Section $3 .^{30}$

$\pi$ 67,324 (N.D. Ill. 1953) (enjoins coercion of dealers). Ford and Chrysler entered inte almost identical consent decrees. United States v. Ford ALotor Co., id. $r$ 67,437 (X.D. Ind. 1953) ; United States v. Chrysler Corp., id. T 67,438 (N.D. Ind. 1953).

25. The facts are set out in United States v. General Alotors Corp., 121 F.2d 37u, 385 97 (1941).

26. Id. at 404.

27. Ibid.

28. Id. at 402.

29. "But even if the single trader doctrine were applicable, it would not help the appellants. [citing $\$ 3$ tie-in cases]." Id. at 40\%. But cf. United States r. Investurs Diversified Services, Inc, 102 F. Supp. 645 (D. Minn. 1951), 52 CoL L. Rev. 1060 (1952) (loans not sale of commodity under \$3). And see Note, 63 Y.uLE L.J. 389, 390 (1954).

30. 121 F.2d 376, 404 (1941). The unfavorable precedent was Picl. Mfg. Cu. V. ( eral Motors Corp., 80 F.2d 641 (7th Cir. 1935), uffd, 299 L.S. 3 (1936) (tie-in sale of replacement parts permissible under $\$ 3$ to protect good will). See also note 29 supro. 
Tied-in Purchases: The Movie Exhibitor Cases. ${ }^{31}$ The Supreme Court found conspiracy within single enterprises in the Crescent, Griffith, and Schine cases. All involved movie exhibitors owning widespread chains of theaters. $^{32}$ In each case the multi-corporate enterprise owned the only theater in some towns and competed with independents in others. By pooling the buying power of all theaters, the enterprise was able to obtain exclusive privileges from film distributors. These privileges deprived competitors of first- or second-run pictures for unreasonable periods of time. Such abuse of massed buying power violated Sections 1 and 2 of the Sherman Act.

The close-knit form of each defendant corporate group did not prevent at finding of intra-enterprise conspiracy. In Crescent and Griffith, the conspiracy included affiliated corporations and their officers. ${ }^{33}$ In Scline, parent and subsidiary corporations together with their officers were parties to the conspiracy. ${ }^{34}$ In all three cases the defendants were clearly a unified economic unit under centralized control. ${ }^{35}$

Single corporate form would not have avoided Sherman Act liability in any of the movie cases. The Government probably alleged a Section 1 conspiracy to hedge against the possibility that the court would find no "specific intent" to monopolize. Crescent assumed that a single exhibitor engaged in the same plan of economic warfare as the multi-corporate defendant would not run afoul of the Sherman Act. ${ }^{36}$ However, Griffith definitely indicated that a single-trader who used the buying power of an entire circuit to negotiate films for competitive as well as closed towns could violate Sections $2 .^{.37}$

Coercing Price Discrimination: The $A \& P$ Case. ${ }^{38}$ In a criminal prosecution the Seventh Circuit upheld Section 1 conspiracy charges against the

31. Schine Chain Theaters v. United States, 334 U.S. 110 (1948); United States v. Griffith, 334 U.S. 100 (1948) ; United States v. Crescent Amusement Co., 323 U.S. 173 (1944).

32. The Crescent defendants controlled theaters in 70 small towns in five states. In Griffith, the parties had theaters in $\mathbf{8 5}$ towns over a four state area. In Scliinc, the chain consisted of 148 theaters in six states. The facts of the case are set out, as follows: Schine Chain Theaters v. United States, supra note 31, at 113-115; United States v. Griffith, supra note 31, at 102-103; United States v. Crescent Amusement Co., supra note 31 , at $176-82$.

33. United States v. Griffith, stipra note 31, at 101-102; United States v. Crescent Amusement Co., supra note 31 , at 176.

34. Schine Chain Theaters v. United States, supra note 31 , at 116.

35. Schine Chain Theaters v. United States, supra note, 31, at 115; United States v. Griffith, supra note 31, at 102 ; United States v. Crescent Amusement Co., supra note 31, at 178 .

36. United States v. Crescent Amusement Co., supra note 31, at 183.

37. United States v. Griffith, sipra note 31, at 108.

38. United States v. New York Great Atlantic \& Pacific Tea Co., 173 F.2d 79 (7th Cir. 1949), affirming 67 F. Supp. 626 (E.D. Ill. 1946). For differing views see Dirlam \& Kahn, Antitrust Policy and the Big Buyer: Another Look at the $A$ \& $P$ Casc, 60 J. Pol. Econ. 118 (1952); Adelman, The A \& $P$ case: A Study in Applicd Economic Theory, 63 Q.J. ECoN. 238 (1949); Notes, 58 Y ALE L.J. 969 (1949); 47 CoL. L. REv. 786 (1949); 15 U. of CHI. L. REv. 392 (1948). 
A \& $P$ grocery chain. By threatening to boycott suppliers and go into the food business itself, satellite corporations and key officers coerced food suppliers into granting lower prices to ACCO, the buying corporation, than to competing brokers. ${ }^{39}$ These price discriminations were sometimes compounded when ACCO resold to A \& P's retail competitors at higher prices than those charged to A \& P's own outlets.

It is doubtful that $A \& P$ could escape antitrust liability for this practice by becoming a single corporation. The court did not decide whether defendants violated the Robinson-Patman Act. But that statute forbids a buyer knowingly to induce or receive price discriminations. A \& $P$ seems liable under the court's statement of the facts. ${ }^{10}$ However, under a Section 1 theory the Government had a lighter burden of proof, since it avoided the necessity for introducing data to show lack of cost justification. ${ }^{41}$

GIIAC, the Movie Cases, and $A \& P$ illustrate the application of the intraenterprise conspiracy concept to a variety of single-trader abuses-tie-ins, refusals to deal, price discrimination, and unfair use of market leverage. Each of the abuses, although condemned under a conspiracy charge, could have been attacked under other specific provisions of the antitrust statutes. Use of the conspiracy charge gave prosecutors an alternative theory of illegality offering tactical advantages or sanctions not available elsewhere.

The abuses struck down in these cases were of a type long condemned by the antitrust laws. In each case the single-trader was found guilty not of restraining his own trade, but of restraining the trade of third parties. General Motors restrained the trade of independent automobile dealers and finance companies; the movie exhibitors deprived competitors of first-run pictures by obtaining exclusive privileges; $A \& P$ coerced its suppliers into granting it discriminatory prices. The right of an enterprise to restrain its own trade (i.e., fix its own prices or divide its own markets) was not impaired by any of these decisions.

\section{Vertical Integration}

The Yellow Cab Case. ${ }^{42}$ Starting in 1929, the controlling shareholder of a Michigan cab manufacturer initiated a plan for securing control of the taxicab operating business in four key cities. ${ }^{43}$ The enterprise expanded by setting

39. The facts are set out in United States v. New York Great Atlantic \& Pacific Tea Co., 173 F.2d 79, 81-7 (7th Cir. 1949).

40. See sources cited note 16 supra.

41. For a full discussion of the Government's burden of proof in a RobinsonPatman prosecution see Note, 63 YALE L.T. 260 (1953).

42. United States v. Yellow Cab Co., 332 U.S. 218 (1947).

43. The facts are taken from United States v. Yellow Cab Co, supra nute 42, at $220-5$. 
up new operating companies, by buying the stock or assets of existing operators, and by foreclosing chattel mortgages against debtor cab drivers. At the time of the prosecution, the defendants controlled, through interlocking stock ownership, $86 \%$ of the cab licenses in Chicago, $15 \%$ in New York, $100 \%$ in Pittsburgh, and $58 \%$ in Minneapolis. In all, defendants controlled 5000 taxicab licenses. The integrated operating companies bought their cabs exclusively from the manufacturing corporation. In a divestiture proceeding, the manufacturing corporation, its sales subsidiary, and various operating companies were charged with conspiring with their common management to violate Sections 1 and 2 of the Sherman Act.

The Supreme Court reversed lower court dismissal of the complaint. ${ }^{44}$ The Government's allegations revealed at least three grounds for liability on the motion to dismiss. First, limiting the market outlets for other cab manufacturers restrained the trade of third parties. ${ }^{45}$ Second, since the integrated cab operating companies may have been charged "higher than open-market prices" for cabs bought from the parent manufacturer, the defendants were restraining their own trade. ${ }^{46}$ Finally, the integration was an attempt to monopolize since it resulted from calculated purchase for control rather than normal expansion. ${ }^{4 \tau}$ The amount of the market still open to other cab manufacturers was irrelevant, since the 5000 controlled cabs constituted an appreciable segment of the cab-sales market. ${ }^{48} \mathrm{Mr}$. Justice Murphy, for the Court, summarily rejected the single-trader defense to conspiracy. ${ }^{40}$ Separate corporations provided the necessary parties.

The Department of Justice interpreted this theory as damning vertical integration per se. ${ }^{50}$ Every vertical integration to some extent shuts off a market of sale or source of supply from competitors. Moreover, depending on the fortuities of inter-corporate bookkeeping, the enterprise may charge its unit a higher than market price. ${ }^{51}$ Thus the Justice Department's theory would condemn a business that has expanded by building new units, as well as a business that has bought out existing concerns. And if a vertically integrated business encompasses an appreciable volume of commerce, Sherman Act lia-

44. Four opinions are involved: United States v. Yellow Cab Co., 69 F. Supp. 170 (N.D. Ill. 1946), in which the trial court dismissed the complaint; 332 U.S. 218 (1947), reversing the dismissal; 80 F. Supp. 936 (N.D. Ill. 1948), giving judgment to defendants after trial; 338 U.S. 338 (1949), affirming the judgment.

45. United States v. Yellow Cab Co., 332 U.S. 218, 226-7 (1947).

46. Id. at 224-5.

47. Id. at $227-8$.

48. Id. at 226 .

49. Id. at 227 .

50. The Department of Justice interpretation of $Y$ ellow $C a b$ is summarized in United States v. Columbia Steel Co., 334 U.S. 495, 521 (1948).

51. See Hale, Diversification: Impact of Monopoly Power, 98 U. oF PA. L. REv. 320,354 (1950), for discussion of the Government's use of this argument in the current DuPont prosecution. 
bility would follow regardless of the percentage of the market still open to competitors.

In Columbia Steel ${ }^{22}$ the Supreme Court deflated I"cllow Cab. The Court held that U. S. Steel's acquisition of a small west coast fabricator did not violate Section 1 of the Sherman Act. Mr. Justice Reed limited Yollow Cab's holding to the Section 2 offense of attempting to monopolize. The new test for Section 1 was in terms of market control. Since the new subsidiary accounted for only $3 \%$ of the west coast demand for rolled steel, the Court decided that enough of the west coast market for fabricated steel was still open to other steel producers. And because no specific intent to monopolize tainted the transaction U. S. Steel did not violate Section 2.

The area of illegality in vertical integrations has not been expanded by the development of the intra-enterprise conspiracy doctrine. Read together, Iclloci' $C a b$ and Columbia Steel indicate that whether the integration takes single- or multi-corporate form is irrelevant for Sherman Act purposes. If the enterprise was assembled through a union of formerly independent businesses, even a single corporation satisfies Section 1's joint action requirement as a "combination." Liability here depends on market power. And a single corporation, whether it expands by merger or by building a new outlet or source of supply, is vulnerable under a Section 2 monopolization theory if there is an intent to suppress competition. On the other hand, if the integration has no significant effect on competition it is immune under any theory. ${ }^{3}$

\section{Per Se Offenses}

When two or more independent companies agree to fix prices or divide markets, courts find a per se violation of Section $10^{54}$ Since the integrated enterprise fixes its own prices and divides its markets as a matter of coordinated management, business has viewed with alarm the recent combination of per se illegality with intra-enterprise conspiracy..$^{50}$

Market Division: The Timnen Case. ${ }^{\text {"S }}$ American Timken, with its British and French affiliates, was held to have conspired to divide the world market in antifriction bearings in violation of Section 1.57 At the time of the Government's civil prosecution, the three companies manufactured $25 \%$ of the

52. United States v. Columbia Steel Co., 334 U.S. 495, 520-23 (1948).

53. E.g., if U. S. Steel built rather than bought facilities like those of Columbia Sted, no part of an existing market would be foreclosed to competitors. Id. at $\mathbf{5 3 2}$.

54. See cases cited note 5 supra.

55. For the view that the doctrine puts the parent-subsidiary form "in serious geril" see Handler, Contract, Conbination or Conspiracy in Ausericus BrR Asscentro: Section of Aintitrust Law 38 (1953).

56. Timken Roller Bearing Co. v. United States, 341 U.S. 593 (1951), 25 Trus. L.Q. 227; 100 U. of PA. L. Rev. 1026 (1952). See Oppenheim, Forcign Conumerce useder the Sherman Act-Points and Implications of the Timlsen Case, 42 T.M.R. 3, $5-7$ (1952).

57. The facts are set out in the district court opinion, United States v. Timlien Rollcr Bearing Co., 83 F. Supp. 284, 310-12 (N.D. Ohio 1949). 
antifriction bearings in the United States, $20 \%$ of the total British production, and $10 \%$ of the French output. American Timken owned $30 \%$ of British Timken's stock. British and American Timken each owned 50\% of French Timken. The interlocking stock ownership was, however, born in sin. For a period of eighteen years before American Timken bought its interest in the British company the two enterprises had used patent licenses to divide territories. And after the stock purchases, the two companies acted like independents and "jealously guarded" their respective interests. Stock ownership was a way to share profits and enforce market division.

Defendant, American Timken, argued that it had merely engaged in a joint venture with British Timken. ${ }^{58}$ Under this theory the three companies were in effect a single-trader. The market division was, therefore, reasonably incidental to the common enterprise and a permissible restraint. However, the trial court viewed the companies as a loose-knit combination condemned by anti-competitive intent..$^{59}$ They were really independents who had long tried to avoid competing. The stock ownership was an outgrowth of that intent. In organizing French Timken, the conspirators illegally created a joint production and sales agency to share a foreign market. The trial court would have taken a different view if American Timken had built its own plants abroad. ${ }^{60}$ The Supreme Court affirmed on a more comprehensive theory. The Court rejected the joint venture defense. "Perhaps every agrecment and combination to restrain trade could be so labeled." 61 The ambiguous facts fit into alternative molds of Section 1 illegality. On the one hand, the companies were separate contracting parties whose agreements to suppress competition among themselves were illegal per se, regardless of predatory intent. ${ }^{02} \mathrm{On}$ the other hand, they constituted a traditionally illegal combination whose aggregation of trade restraints injured competitors and restricted imports and exports of bearings. ${ }^{63}$

Mr. Justice Jackson's dissent suggests that the majority in Timkan outlaw the corporate subsidiary form of doing business. ${ }^{64} \mathrm{He}$ imputes to the majority the Government's oral argument that divisional form would insulate the companies from Section 1 censure. ${ }^{65}$ Thus, if the three companies reorganized into a single corporation, the joint action requirement of Section 1 could not be satisfied. If correct, such an interpretation of Timken would cripple anti-

58. Defendants' argument is summarized in Note, 100 U. of PA. L. REv. 1006, 1016 (1952).

59. 83 F. Supp. 284, 306, 310-11 (N.D. Ohio 1949).

60. Id. at 306,312 . For a similar view see United States v. Minnesota Mining \& Mfg. Co., 92 F. Supp. 947, 963 (D. Mass. 1950).

61. 341 U.S. 593, 598 (1951) (emphasis supplied).

62. Ibid.

63. Ibid.

64. Id. at 607.

65. Mr. Justice Jackson's dissent quotes the Government's oral argument, id. at 606-07. 
trust enforcement. And that interpretation goes too far. Under Jaclsson's view the enterprise would be liable per se if it built rather than bought a foreign subsidiary and allotted an appropriate territory to each corporation.

To read Timken in this fashion would undermine the useful functions of the corporate subsidiary form of doing business. Affiliates and subsidiaries serve many legitimate business purposes : ${ }^{61}$ increasing facility in financing; avoiding the difficulty or impossibiltiy of qualifying the parent company as a foreign corporation in a particular state; $; 0$ avoiding complications involved in the purchase of physical assets; retaining the good will of an established business unit; minimizing taxation ;8s securing managerial efficiency; limiting tort and contract liability. ${ }^{69}$ Moreover, the subsidiary form is often the only effective way of competing in a foreign country. ${ }^{70}$ It avoids otherwise insuperable barriers to foreign trade like high tariffs, quota restrictions, and currency controls.

The majority in Tinkon doubtless intended a less startling theory of antitrust illegality. The venerable Ancrican Tobacco case, ${ }^{71}$ cited by the Court, casts light on the majority view. American Tobacco had purchased interests in foreign corporations with a view towards dividing the world market. Just as in Timken, the acquired corporations remained ostensibly independent cumpetitors of American Tobacco. The 1911 Supreme Court presaged Tint:nen's holding: "[T] he assailed combination ... whether looked at from the point of view of stock ownership or from the standpoint of the principal corporation and the subsidiary corporations, viewed independently, . . . comes within the prohibitions of the ... Sherman Act."72 So also the facts in Timlen wavered between alternative patterns of Section 1 liability. The majority probably meant: insofar as the parties acted like independent competitors before and after integration, market division is illegal per se; insufar as they are integrated, it is an illegal combination condemned by the rule of reason.

This view of Timken accords with the Supreme Court's theory in Columbia Steel, ${ }^{73}$ decided three years before Timken. In addition to the vertical integration involved there, the acquired company was also a former competitor

66. For a discussion of business purposes of the multi-corporate organization, see Douglas \& Shanks, Insulation from Liability through Sudsidiary Corporations, 39 YALE L.J. 193 (1929); Dewing, The Funanclal Policy of Corforatro:ss 1065-80 (1946).

67. Interstate Transit Lines v. Commissioner, 319 U.S. 590 (1943) (Nebraska corporation organizes subsidiary in California to engage in intra-state transportation business otherwise barred to foreign corporations).

68. For income tax and excess profits tax advantages, see Jensen, Tax Effects of Splitting a Corporation into Two or More Units, $92 \mathrm{~J}$. Accoustinscy 294, 295 (1951).

69. Latty, Subsidiaries and Affiliated Corporitions 192-220 (1936).

70. See Timken Roller Bearing Co. v. United States, 341 U.S. 593, 603, $605-03$ (1951) (dissenting opinions).

71. United States v. American Tobacco Co., 221 U.S. 105 (1911).

72. Id. at 184 .

73. United States v. Columbia Steel Co., 334 U.S. 495, 527-31 (1948). 
of U. S. Steel in structural steel fabrication and in the mantufacture of pipe. Although the acquired subsidiary would doubtless be a party to intra-enterprise market division after its purchase, the Court approved the transaction. To determine the legality of the combination, the Court looked to the percentage of the market controlled, the strength of remaining competition, the purposes of the acquisition, the probable development of the industry, and consumer demand for the product. ${ }^{74}$ And if $U$. S. Steel had built rather than bought the west coast fabricator, there would be no Section 1 liability. ${ }^{75}$

In accord with the Columbia Steel theory, the district court in the Imperial Chemicals case ${ }^{76}$ did not interpret Timken to condemn the corporate stbsidiary form. There DuPont was held to have violated Section 1 by sharing ownership of foreign corporations with an English competitor. The joint ownership was part of a plan to divide the world market in munitions and other commodities. The district court's decree expressly ordered DuPont to maintain wholly-owned subsidiaries instead of the jointly-owned companies. ${ }^{77}$

Price Fixing: the Kiefer-Stewart Case. ${ }^{78}$ Kiefer-Stewart, an Indiana liquor wholesaler, won treble damages from two affiliated liquor producers. The defendants, Seagram and Calvert, cleprived the wholesaler of his liquor supply when the wholesaler refused to resell at certain maximum prices fixed by the producers. Neither Indiana nor federal fair trade legislation protected maximum resale price maintenance. ${ }^{79}$

The liquor distributors argued that they were in fact a single-tracler, exercising a unified business' right to set the terms on which it would cleal..$^{80}$ Defendants tried to distinguish earlier cases rejecting the single-trader defense. The argument was that earlier cases had condemned single-traders only when they engaged in "coercive" practices. The alleged restraint in Kiefer-Stezvart, defendants claimed, was merely "voluntary." Both affiliates had willingly agreed to set resale prices, as a matter of internal business policy.

74. Id. at 527 .

75. Id. at $\mathbf{5 3 2 .}$

76. United States v. Imperial Chemical Industries, 100 F. Supp. 504, 592 (S.D.N.Y. 1951) (territorial division constitutes a restraint); United States v. Imperial Chemical Industries, 105 F. Supp. 215 (S.D.N.Y. 1952) (decree).

77. Id. at 242 .

78. Kiefer-Stewart Co. v. Joseph E. Seagram \& Sons, Inc., 340 U.S. 211 (1951). For discussion see Comment, 18 U. of CrI. L. REv. 369, 376 (1951); Note, 21 TEnv. L. Rev. 881 (1951).

79. The Indiana statute protects only minimum price maintenance. Ind. ANn. Srst. $\S 66-302$ (Burns, 1937). The Miller-Tydings Act, in effect at the time, protected only minimum price fixing allowed by state statute. 50 STaT. 693 (1939), as amended, 15 U.S.C. § 1 (1946).

80. For defendants' argument See The Supreme Court, 1950 Term, 65 HAkv. L. Rev. 107, 122-3 (1951). The argument was proposed by Rahl, Conspiracy and the Anti-Trist Lawe, 44 ILl. L. Rev. 743, 766 (1950). 
The Supreme Court reversed the Seventh Circuit and upheld plaintiff's million dollar recovery against the distributors. ${ }^{81}$ The producers conspired to fix prices. ${ }^{82}$ The Seventh Circuit incorrectly thought the price fixing was justified as a weapon against monopolistic combinations of liquor wholesalers. ${ }^{83}$ But price fixing is illegal per se under Section 1 of the Sherman Act.8 The fact that both defendants were under common ownership and control did not prevent a finding of conspiracy "especially ... where, as here, respondents hold themselves out as competitors." $\$ 5$ The Court ignored defendants' distinction between "voluntary" and "coercive" restraints.

The Antimonopoly Bureau of the FTC read Kiefer-Stcuart broadly. Nine months after the Supreme Court opinion, the Bureau brought separate complaints against the two largest liquor distiller-distributors. ${ }^{80}$ The complaints charge Seagram and Schenley with conspiracy among their respective subsidiary corporations. The offense is price fixing in violation of Section $\mathbf{5}$ of the Federal Trade Commission Act. The FTC attack is purely and simply on the defendants' form of business organization. The companies apparently indicated they might reorganize their businesses into single corporations. FTC prosecutor in charge of the case then explained, "It is possible that these two companies might reorganize on a divisional basis, in which event the basic part of the causes of action stated in the complaints would be removed." 83

The FTC attack is probably designed to curtail each distiller's practice of putting out several brands. An oligopolist uses separate brands to secure maximum profits. ${ }^{89}$ The seller segregates the market by products differentiated through advertising to make as many separate bargains as possible. ${ }^{.0}$ "It is not unusual for the identical product to be bottled under several different labels and at different prices. ..."01 Forcing divisional reorganization upon distillers cramps this practice in two ways. Federal and state adver-

81. Plaintiff recovered $\$ 975,000$ plus $\$ 50,000$ attorney fees. 182 F.2d 228,229 (7th Cir. 1950).

82. 340 U.S. 211,213 (1951).

83. 182 F.2d 228, 233-4 (7th Cir. 1950). The circuit court also thought no concert between defendants was established. Id. at 234. Eut the Supreme Court held there vas agreement. 340 U.S. 211, 213-14 (1951).

84. Id. at 213 .

85. Id. at 215 .

85. Distillers Corporation-Seagrams, Ltd., FTC Dlit. 6047 (pending); Schenley Industries, Inc., FTC Dkt. 6048 (pending); 3 CCH TRADE REo. Res. T11,203 (complaints issued Sept. 24, 1952).

87. For full discussion of the liquor companies' probable plan to abolish their subsidiaries and this plan's consequences, see The Wall Street Journal, December \&, 1953, p. 1 , col. 4.

8S. Communication to the Yale Law Jourarac from FTC Bureau of Antimonopoly, dated December 15, 1952.

89. GeMrinl, Fundansentals of Economics 398 (4th ed. 1943).

90. Id. at 414 .

91. Borregard \& Glusker, The Distulled Splatrs Innustryy: A Mialineti:a SibvEy 145 (unpublished thesis in Yale Law School Library, 1950). 
tising regulations might require all brands of the same company to mention the company's name on the label..$^{92}$ And one corporation cannot do business under several brand names in some states. ${ }^{93}$

Such a roundabout attack on the symptoms of oligopoly is absurd. It seems doubtful that forced reorganization would substantially curtail the monopolistic profits that accrue when a few big sellers find their self-interest served by advertising competition rather than by price competition. Oligopoly profits would continue even if each large seller were restricted to a single brand.94 Moreover, the FTC need not charge conspiracy to attack these branding practices. Section 5 condemns unfair and deceptive methods of competition regardless of conspiracy. ${ }^{05}$ The net effect of the FTC attack would be greater integration rather than less. And the Antimonopoly Bureau's broad reading of Kiefer-Stezvart, if followed by the courts, opens the door to unwarranted treble damage suits against multi-corporate business. Since any well-run multi-corporate business coordinates price policy, treble damage claimants could always show a price fixing conspiracy.

The facts of Kiefer-Stewart do not support the FTC's interpretation. The Supreme Court was not dealing with simple price fixing but with resale price maintenance, enforced by a refusal to sell. The Maguire Act of 1952 now legalizes Seagram's and Calvert's behavior, if state statutes also allow the practice. ${ }^{96}$ But without that protection, resale price fixing by a single-trader is clearly illegal. ${ }^{97}$ The Shrader's Son case had condemned price maintenance contracts implied from a course of dealing. ${ }^{98}$ And on the Becch-Nut case theory, ${ }^{99}$ the FTC has enjoined attempts by a single corporation to install a system similar to Seagram's plan regardless of contract. ${ }^{100}$ But private parties cannot sue under Section 5 of the Federal Trade Commission Act on which the Government usually based its prosecution. ${ }^{101}$ Kiefer-Stewart did not extend the area of practice illegal to single-traders, but rather extended the treble damage remedy to injured parties.

92. Krasney, The FTC Complaius, J. of Commerce, October 3, 1952, p. 9, cols. 4-5.

93. Ibid.

94. Rostow, The New Sherman Act: A Positive Instrmment of Progress, 14 U. of ChI. L. REv. 567, 576-7 (1947).

95. 38 StaT. 719 (1914), 15 U.S.C. $\$ 45$ (1946).

96. 66 Stat. 631 (1952), 15 U.S.C.A. $\$ 45$ (Supp. 1952).

97. Comment, 19 U. OF CHI. L. REv. 837, 849-61 (1951), and cases cited therein.

98. United States v. A. Schrader's Son, Inc., 252 U.S. 85 (1920).

99. FTC v. Beech-Nut Packing Co., 257 U.S. 441 (1922).

100. See, e.g., Hill Bros. v. FTC, 9 F.2d 481 (9th Cir. 1926), ccrt. denied, 270 U.S. 662 (1926) (keeping a "do-not-sell" list); Q. R. S. Music Co. v. FTC, 12 F.2d 730 (7th Cir. 1926) (procuring agents and retailers to report price cutters) ; Moir v. FTC, 12 F.2d 22 (1st Cir. 1926) (informing dealers that price cutters will be refused sales).

101. Samson Crane Co. v. United National Sales, Inc., 87 F. Supp. 218 (D. Mass. 1949), aff'd mem., 180 F.2d 896 (1st Cir. 1950) (dismissing private suit for want of jurisdiction). Cf. Proper v. John Bene \& Sons, 295 Fed. 729 (E.D.N.Y. 1923) (denying admission of FTC order in private suit). 
Timken and Kiefer-Stea'art indicate the Supreme Court's willingness to find conspiracy when a single-trader injures other businesses by its anticompetitive conduct. Neither case provides support for the argument that restraint of one's own trade is illegal per se. The interpretation apparently given these cases by enforcement agencies should not be followed.

\section{Conspiracy within the Single Corporation}

While fearing that multi-corporate form might be offensive per se, antitrust defendants have argued hopefully that single corporate form is a complete defense to intra-corporate conspiracy charges. Although some courts have accepted this view by refusing to find the two or more parties essential to conspiracy in the officers, directors, and agents of the single corporation, the Supreme Court has left this question open.

The recent Motorola case ${ }^{102}$ was a treble damage suit charging a single corporation with conspiring to violate Section 1 of the Sherman Act. ${ }^{103}$ Plaintiff, a wholesale distributor of electrical appliances, sold in various counties in Alabama and Florida assigned to him by his supplier, Motorola. In 1949, Motorola refused to renew his one-year franchise. The refusal stemmed from a dispute about whether the wholesaler's franchise should include commercial communications equipment in addition to the radios, phonographs, and television sets he had been licensed to distribute. Motorola insisted (a) on marketing its communications equipment through its own agencies, (b) on prohibiting the wholesaler from handling its competitors' communications equipment. When plaintiff did not accept these terms, MLotorola refused to renew his franchise. The wholesaler's principal legal theory was that Motoralo's officers had conspired to restrain trade by refusing to deal with him.

The Fifth Circuit upheld trial court dismissal of the complaint, one judge dissenting. ${ }^{104}$ Single corporate form was a defense per se. Given multicorporate form, the court indicated it would find conspiracy. ${ }^{105}$ But the court said it is "absurd" to believe a single corporation "conspired with itself to restrain its trade in its own products."100 The corporate officers could not be parties to the conspiracy since they "were only acting for the defendant corporation." 107 Nor could plaintiff complain that Motorola's conduct was a

102. Nelson Radio \& Supply Co. v. Motorola, Inc, 200 F2d 911 (5th Cir. 1952), cert. denied, 345 U.S. 925 (1953).

103. The facts are taken from the opinion of the court, Nelson Radio \& Supply Co. v. Miotorola, Inc, supra note 102, at 912-13, and from Appellant's Brief, pp. 2-4.

104. Nelson Radio and Supply Co. v. Motorola, Inc., supra note 102.

105. Id. at 914.

106. Ibid.

107. Ibid. 
single person offense. Even if the contract sought to be imposed was illegal under Section 3 of the Clayton Act, that Act does not apply since the plaintiff was injured not by a sale but by a refusal to sell. ${ }^{108}$ The court nowhere analyzes possible anti-competitive effects of defendant's conduct.

A recent district court opinion follows Motorola in refusing to recognize intra-corporate conspiracy. ${ }^{109}$ The court dismissed a complaint charging the Carnation Company and its officers with conspiring to drive small purchasers in an Arkansas milkshed out of business by maintaining abnormally high prices. ${ }^{110}$

The Motorola and Carnation holdings are in apparent conflict with cases in two other circuits. In Patterson v. United States, ${ }^{111}$ the Sixth Circtit upheld conspiracy charges against twenty-eight officers and agents of a cash register corporation. The corporation itself was not a party to the criminal antitrust prosecution. Defendants secured control of $95 \%$ of the cash register market after harassing competitors with spies, bribes, and threats of patent infringement suits. The Government prosecuted under Sections 1 and 2 of the Sherman Act. Similarly, in White Bear Theater Corp. v. State Theatcr Corp., ${ }^{112}$ the Eighth Circuit held that a single movie exhibitor corporation and its officers conspired to violate Sections 1 and 2. The court awarded treble damages to another theater almost driven out of business by defendant's practice of buying more films than it needed. Both White Bear and Patterson possibly may be distinguished on their facts as attempts to monopolize. ${ }^{113}$ But in both cases, defendants also violated Section 1. Despite this doctrinal clash on whether a single corporation can conspire with itself, the Supreme Court refused to review Motorola. ${ }^{114}$

The Fifth Circuit's view in Motorola should not be followed. Kiefer-Stcreart ${ }^{115}$ is authority for a contrary view. In the liquor wholesaler decision, a multi-corporate single enterprise satisfied the joint action requirement of Section 1. It seems anomalous that artificial persons within a single enterprise

108. Id. at 915 .

109. Marion County Co-op. Ass'n v. Carnation Co., 114 F. Supp. 58 (W.D. Ark. 1953).

110. Id. at 63.

111. 222 Fed. 599, 633 (6th Cir. 1915), cert. denied, 238 U.S. 635 (1915). The court reversed the district court on other grounds. Id. at 626 .

112. 129 F.2d 600 (8th Cir. 1942).

113. Plaintiff in Motorola would have done well to allege a $\$ 2$ violation in addition to the $\S 1$ charge. Courts have held that refusals to deal may constitute an attempt to monopolize. See, e.g., Eastman Kodak Co. v. Southern Photo Materiais Co., 273 U.S. 359 (1927) (refusal to sell to wholesaler is attempt to monopolize distribution of $\mathrm{film}$ ); United States v. Klearflax Linen Looms, Inc., 63 F. Supp. 32 (D. Minn. 1945) (withholding deliveries of rugs to distributor is attempt to monopolize). For analysis sec Comment, 58 YALE L.J. 1121, 1135 (1949).

114. Nelson Radio \& Supply Co. v. Motorola, Inc., 345 U.S. 925 (1953).

115. Kiefer-Stewart Co. v. Joseph E. Seagram \& Sons, Inc., 340 U.S. 211 (1951). See sources cited note 78 supra. 
can conspire for Section 1 purposes, while real persons within a single corporation cannot do so. The Supreme Court has often held that businesses may not avoid antitrust liability by accidents of form. ${ }^{110}$ In both .Motorola and Kiefer-Stewvart, defendants used refusal to deal as a weapon to effectunte practices forbidden by the antitrust laws. Section 3 of the Clayton Act may well forbid Motorola's sales to its seventy-nine distributors on the condition that they refrain from dealing with competitors. ${ }^{117}$ Such a prohibtion is at least as clear as the policy forbidding resale price maintenance when unprotected by fair trade laws. ${ }^{118}$

Finding intra-corporate conspiracy would not engulf in per se illegality every business refusing to sell to a willing buyer. In the Motorola situation, defendant can assert the traditional defenses to treble damage actions. ${ }^{110}$ Private suitors must prove their injury was caused by the alleged illegal practices. ${ }^{120}$ Courts will deny recovery if the refusal to deal is a "private controversy" in which "the public interest is not involved."121 And the oft-expressed dictum that all concerted refusals to deal are illegal per se does not necessarily mean what it says. The Supreme Court has never condemned a refusal to deal without a "thorough canvassing of the facts." Originators' Guild case, thought to stand for illegality per se, indicates that group boycotts could be justified by the rule of reason. ${ }^{123}$ The determinants of legality are the purpose of the refusal, its effects on competition, and the market power of defendants. ${ }^{124}$ Defendants' form of organization should be irrelevant to antitrust enforcement.

\section{ConcLusion}

The joint action requirement of Section 1 of the Sherman Act need not hinder antitrust enforcement. In the modern business world multiple parties are always available to constitute a combination, contract, or conspiracy.

116. See, e.g., United States v. Masonite Corp., 316 U.S. 265, 278 (1942); United States v. American Tobacco Co., 221 U.S. 106 (1911).

117. See, e.g., Standard Fashion Co. v. The Magrane-Houston Co., 258 U.S. 346 (1922) (agreement not to handle competitors' goods); Thomson Mfg. Co. v. FTC, 150 F.2d 952 (1st Cir. 1945), cert. denied, 326 U.S. 776 (1945) (same). The legality of Motorola's plan has yet to be tested.

118. See text at note 97 supra.

119. See Comment, 61 YALE L.J. 1010, 102S-33 (1952).

120. Id. at 1016.

121. Fedderson Motors, Inc. v. Ward, 180 F.2d 519, 521-2 (10th Cir. 1950) (denying recovery for franchise termination); Arthur v. Kraft-Phenix Cheese Corp., $26 \mathrm{~F}$. Supp. 824,828 (D. M1d. 1938) (same).

122. Comment, 58 Y ALE L.J. 1121, 1138 (1949).

123. "The purpose and object of the combination, its potential power, its tendency to monopolize, the coercion it could and did practice ... all brought it within the policy of the prohibition." Fashion Originators' Guild of America v. FTC, 312 L.S. 457, 467 (1941).

124. Comment, 58 Yale L.J. 1121, $1138-9$ (1949). 
Courts have consistently held that a multi-corporate unified business satisfies the joint action formula. The officers of a single corporation should likewise be separate persons for purposes of antitrust enforcement.

Overemphasis on the conspiracy aspect of a Section 1 violation, however, leads to strange results. By combining intra-enterprise conspiracy and per se restraints, antitrust enforcement agencies have made the form of organization the determinant of legality. The Justice Department and FTC prosecutors have conceded that single corporate form is a defense per se. ${ }^{126}$ The Antimonopoly Bureat of the FTC has suggested that multi-corporate form is an offense per se. ${ }^{126}$ Fortunately, the decisions do not support either view. Only the questionable holdings in Motorola and Carnation indicate that a single corporation is immune from Section 1. And in every case in which an intraenterprise conspiracy was found, defendants would have been liable for an alternative single-person offense.

The true single-trader defense is not concerned with conspiracy at all. It is grounded in the proposition that, absent monopoly, restraints within the confines of a single enterprise, i.e., internal price and distribution policies, have no harmful effects on competition. And it would seem to make little difference whether the business were conducted in single- or multi-corporate form, as long as a common management controlled throughout. The crucial question is whether trade of third parties is restrained. This depends on the effect of defendant's conduct on suppliers, customers, and competitors. Not since $G M A C$ has the argument been made. ${ }^{127}$ But if defendlants in a proper case could show that only a single-trader's own commerce was restrained, the rule of reason argues strongly that the contention would be upheld.

125. See Timken Roller Bearing Co. v. United States, 341 U.S. 593, 607 (1951) (dissenting opinion).

126. See text at note 88 supra.

127. See text at note 26 supra. 